Germination in Azolla filiculoides Lam. as seen by SEM and thin-sectioning

\author{
D. G. Dunham and K. Fowler
}

Department of Biological Sciences, Portsmouth Polytechnic, Portsmouth PO1 2DY, Hants, U.K.

Current taxonomic re-evaluation of Azolla by the authors presented the opportunity to employ SEM and thin-sectioning to provide photographic illustration of germination stages. The megaspore apparatus, with attached indusial cap, is released from the floating sporophyte by equatorial splitting of the megasporocarp/megasporangial walls. It immediately sinks, indicating that 'floats' do not endow buoyancy. Released microsporangia also sink to the bottom before liberating massulae. Within the megaspore apparatus, the symbiont Anabaena azollae Stras appears to be 'resting' and restricted to the distal space between the megasporocarp and megasporangial wall. The latter is fused to the funnel of suprafilosum folded back over the 'floats'. The female gametophyte develops between the 'floats' within the cylinder of suprafilosum. Its growth pushes the indusial cap upwards, displacing the 'floats'; this displacement probably provides access to the archegonia for the multiflagellate antherozoids. Morphological and histological evidence suggests that $A$. azollae is no longer dormant at this stage. Early embryo development is associated with receipt of the $A$. azollae to perpetuate the symbiotic relationship. Growth of the funnel-shaped 'cotyledonary' leaf ruptures the megasporangial wall, so providing access and a channelled route between Anabaena and the embryo shoot apex. Subsequent leaf development severely restricts such access. The Anabaena colony becomes established behind the apex around a branched trichome which appears morphologically different from those in leaf cavities. Unlike the 'cotyledonary' leaf, subsequent leaves develop cavities into which apically-derived Anabaena becomes incorporated. The developing sporophyte, its apex enclosed by the first leaf, pushes off the indusial cap and rises to the surface in a vertical position still attached to the megaspore apparatus. Buoyancy is probably due to development of leaf cavities and intercellular spaces, the megaspore apparatus sinking immediately on detachment. The elongating sporophyte assumes a horizontal habit; first and second leaves are entire, subsequent leaves are bi-lobed and alternately inserted.

\title{
Molecular biological events of imbibing and germinating spores of Anemia phyllitidis L. Sw.
}

\section{A. Fechner and H. Schraudolf}

Universität Ulm, Abt. Allgemeine Botanik, D-7900 Ulm, F.R.G.

In spores of the fern Anemia phyllitidis, induction of germination requires light, or the presence of the Anemia antheridiogens or gibberellic acid. The capacity of imbibed spores to germinate is retained for more than 6 weeks even if there are repeated cycles of drying and rehydration. Imbibition and germination have been studied at the translational and transcriptional levels. 
The general concepts of imbibition and germination assume only passive water uptake to occur during imbibition, and biosynthetic activity to be restricted to the period of germination. In contrast to these concepts, we have evidence for protein and RNA synthesis during imbibition: proteins extracted from spores imbibed in a medium containing a mixture of ${ }^{14} \mathrm{C}$-amino acids show significant rates of incorporation; electrophoretic separation of labelled protein demonstrates radioactivity for all detectable proteins; all fractions of RNA of imbibed spores are labelled after incubation either with ${ }^{3} \mathrm{H}$-adenosine or ${ }^{3} \mathrm{H}$-uridine.

There are no obvious differences between the in vitro translation products of poly(A) ${ }^{+}$RNA isolated from dry or imbibed spores and the in vivo proteins. Stored poly(A) ${ }^{+}$RNA translatable in a cell-free system therefore seems to have no evident significance for early processes of germination.

Induction of germination with gibberellic acid or light leads to an increase of the rates of translation and transcription. The pattern of in vivo labelled proteins does not change during the first 72 hours after induction of germination. At this time, an additional band of protein (approximately 20,500 d) becomes detectable. The same result was found for the pattern of in vitro translation products. However, the $20,500 \mathrm{~d}$ protein becomes visible after only 48 hours. The appearance of this protein is the only evident qualitative difference between dry, imbibed or induced spores in the pattern of proteins. Since this protein appears when more than $50 \%$ of spores are in mitosis or already have separated the rhizoid initial, we feel that it cannot be regarded as a likely candidate for a molecular signal or indicator of early events of germination.

\title{
Spore germination of two tree-ferns
}

\author{
G. M. Felippe, L. M. Esteves, W. M. Ferreira and Therezinha S. Melhem \\ Departamento de Fisiologia Vegetal, cp 6109, Universidade Estadual de \\ Campinas, 13100 Campinas, Brazil
}

In Southern Brazil, the tree-ferns are amongst several species in danger of extinction. Also, in Brazil, only classical taxonomic studies have been carried out on tree-ferns. Thus, it was decided to initiate a germination study of two members of the Cyatheaceae-Trichipteris corcovadensis and Cyathea delgadii. The spores were collected from plants occurring in the Sao Paulo Botanic Gardens. In the case of Trichipteris corcovadensis, spores of 5 different specimens were collected (11066 A,B,C,D,E). The spores were germinated in Knop's solution with the modification given by Dyer (1979). The criterion of germination was the emergence of the rhizoid. The external morphology of the spores was studied under the optical microscope (after acetolysis) and under the scanning microscope.

Cyathea delgadii: the spores were $100 \%$ positively photoblastic. The viability decreased rapidly and the germination was very low after 2 years' storage at $4{ }^{\circ} \mathrm{C}$. Germination was better under the lowest light intensities used and was not affected by photoperiod. The range of constant temperatures in which germination occurred was from 15 to $30^{\circ} \mathrm{C}$. The duration of the light induction period was at least $1 \mathrm{~h}$ (red light). Germination was promoted by both red and blue light and their actions were reversed by far red. 